\title{
CULTIVATION OF Agaricus blazei ss. Heinemann USING DIFFERENT SOILS AS SOURCE OF CASING MATERIALS
}

\author{
Félix Gonçalves de Siqueira ${ }^{1}$; Eustáquio Souza Dias ${ }^{1 *}$; Romildo da Silva ${ }^{1}$; Emerson Tokuda \\ Martos $^{1}$; Danny Lee Rinker ${ }^{2}$ \\ ${ }^{l}$ UFLA - Depto. de Biologia, C.P. 3037 - 37200-000 - Lavras, MG - Brasil. \\ ${ }^{2}$ University of Guelph - Vineland Campus, 4890 Victoria Avenue North, P.O. Box 7000, Vineland Station, Ontario, \\ Canada LOR 2EO. \\ *Corresponding author <esdias@ufla.br>
}

\begin{abstract}
Commercial productivity of the Agaricus blazei mushroom is closely related to both the quality of the compost and the choice of soil to be used as a casing material. This study aims to evaluate Agaricus blazei's productivity using two compost formulations and three soils. The two compost formulations were (i) crushed sugarcane bagasse (Saccharum officinarum (L.)) and Coastcross hay (Cynidon dactylon (L.) Pers.), and (ii) crushed sugarcane bagasse (Saccharum officinarum (L.)) and corn husk (Zea mays L.); they were amended with wheat bran, lime, gypsum, superphosphate and urea. The casing materials were extracted from three soils classed as Rhodic Hapludox, Xanthic Hapludox, and Humic Haplaquox. The Rhodic Hapludox soil material was mixed with fragments of Eucalyptus charcoal in the proportion of 4:1. The compost was prepared during six weeks and thereafter heat treated during $48 \mathrm{~h}$ at the end of the composting period. The sugarcane bagasse:coast-hay compost was superior to the sugarcane bagasse: corn husk compost. The Rhodic Hapludox plus charcoal casing material showed to be a better casing material than either the Xanthic Hapludox and Humic Haplaquox soil materials. The choice of the soils where the casing material is taken is an important factor to the success of the Agaricus blazei mushroom cultivation.

Key words: mushroom cultivation, productivity, compost, fruiting indu ction
\end{abstract}

\section{CULTIVO DE Agaricus blazei ss. Heinemann USANDO DIFERENTES SOLOS COMO FONTE DE MATERIAL PARA ACAMADADE COBERTURA}

\begin{abstract}
RESUMO: A produtividade do cogumelo Agaricus blazei depende da qualidade do composto e da terra de cobertura. Avaliou-se a produtividade deste cogumelo utilizando-se duas formulações de composto e materiais retirados de três tipos de solo usados como camada de cobertura. As duas formulações de composto consistiram em (i) bagaço de cana-de-açúcar (Saccharum officinarum (L.)) e capim Coastcross (Cynidon dactylon (L.) Pers.), e (ii) bagaço de cana-de-açúcar (Saccharum officinarum (L.)) e palha de milho (Zea mays L.). As duas formulações foram suplementadas com farelo de trigo, calcário, gesso, superfosfato simples e uréia. Como camadas de cobertura foram usadas materiais retirados de um Latossolo Vermelho distroférrico (LVdf), um Latossolo Amarelo distrófico (LAdi) e um Gleissolo melânico (GSm). O material retirado do LVdf foi misturado com carvão vegetal na proporção de 4:1. O composto foi preparado durante seis semanas e pasteurizado com vapor d'água por $48 \mathrm{~h}$ ao final do processo de compostagem. O composto bagaço de cana:capim Coastcross foi superior ao composto bagaço de cana: palha de milho, enquanto que o material retirado do LVdf e misturado com carvão vegetal foi melhor como camada de cobertura, em comparação ao LAdi e GSm. A escolha do solo onde será retirado o material a ser utilizado como camada de cobertura pode ser fator determinante no sucesso do cultivo do cogumelo Agaricus blazei.

Palavras-chave: cultivo de cogumelos, produtividade, composto, indução da frutificação
\end{abstract}

\section{INTRODUCTION}

The cultivation of Agaricus blazei ss. Heinemann (Wasser et al., 2002) on a commercial scale in Brazil is relatively recent and needs appropriate technologies development. One of the most important aspects is the choice of the casing material. The kind of this material is responsible in creating the mycelium's appro-

Sci. Agric. (Piracicaba, Braz.), v.66, n.6, p.827-830, November/December 2009 
priate microenvironment which induces the formation of the primordia or mushroom fruiting bodies (Flegg et al., 1985). This process consists, mainly, in the addition of soil and/or other materials over the colonized substrate. In Europe and North America Sphagnum peat moss is successfully used for the Agaricus bisporus cultivation. In Brazil, the commercial exploitation of peat is regulated by environmental legislation and good quality peat for mushroom production is not easily found (Eira, 2003).

In Brazil, casing materials from local soils have been traditionally used for $A$. blazei cultivation. Limestone and charcoal are mixed with it in order to correct the $\mathrm{pH}$ and improve the porosity, respectively (Kopytowski Filho et al., 2006). However, information on the best kinds of soils to be used as casing materials is scarce. Therefore, this study aimed to evaluate the productivity and the biological efficiency using two formulations of substrate and three kinds of soils as casing material in the cultivation of Agaricus blazei ss. Heinemann.

\section{MATERIALAND METHODS}

The spawn of Agaricus blazei strain CS1 was prepared with rice hulls and enriched with $10 \%$ wheat bran. Rice hulls were first precooked in tap water for $30 \mathrm{~min}$ and the excess water drained. Then, the hulls were mixed with the wheat bran and $300 \mathrm{~mL}$ of the mixture placed in glass bottles. The substrate was autoclaved at $121^{\circ} \mathrm{C}$ for $1 \mathrm{~h}$, cooled for 24 hours and then re-autoclaved for an additional hour. After cooling to room temperature, the mixture was inoculated with $A$. blazei from agar cultures. The mycelium was incubated at room temperature, which ranged between 20 and $28^{\circ} \mathrm{C}$ for three weeks.

Two compost formulations were prepared. One compost was prepared from crushed sugarcane bagasse (Saccharum officinarum (L.), derived from the production of cachaça (45 kg), Coastcross' hay (Cynidon dactylon (L.) Pers.) (45 kg), wheat bran $(10 \mathrm{~kg})$, limestone $(2 \mathrm{~kg})$, gypsum $(2 \mathrm{~kg})$, superphosphate $(1 \mathrm{~kg})$ and ammonia sulphate $(1 \mathrm{~kg})$, resulting in a calculated initial nitrogen concentration of $1.1 \%$. The second compost was similar to other with only the Coastcross hay being replaced with chopped corn husk and corncobs (Zea mays L.) (45 $\mathrm{kg}$ ), resulting in a calculated initial nitrogen concentration of $0.9 \%$.

All raw materials were first dried at $65^{\circ} \mathrm{C}$ for 48 $\mathrm{h}$ before being weighed for chemical analysis. Total nitrogen of the raw materials was determined through the Kjeldahl method. Compost preparation required routine mixing and wetting of the materi- als. The compost ingredients must be able to uniformly absorb water; for Coastcross hay formulation, it was first immersed in water for a few minutes. The other materials did not require a pre-wetting step prior to commencement of composting. The wetted hay or corn husk and corncobs and crushed sugarcane bagasse were layered in a wooden frame $\left(1 \mathrm{~m}^{3}\right)$. During the initial layering the materials were watered to runoff. The substrates were usually removed, mixed and re-turned to the frame on Monday, Wednesday and Friday over a period of six weeks when the compost temperature decreased below $40^{\circ} \mathrm{C}$. Water was added as needed. On the fourth turn the wheat bran, limestone, gypsum, superphosphate and ammonia sulphate were mixed into the substrate after verifying that the substrate was sufficiently moist by manually squeezing it and looking for water droplets to appear.

Substrates were steam pasteurized to eliminate or reduce insects and contaminating microorganisms. Post-composting heat treatment was divided into two $12 \mathrm{~h}$ segments. During the first segment, the substrate temperature was increased to $60-82^{\circ} \mathrm{C}$ with live steam and held for minimally $12 \mathrm{~h}$. Subsequently, the compost was mixed in order to assure uniform heat treatment. Following this, the substrate was reheated again to $60-82^{\circ} \mathrm{C}$ for $12 \mathrm{~h}$ and then cooled for spawning. After cooling to approximately $25^{\circ} \mathrm{C}$, the compost (10 $\mathrm{kg}$ ) was thoroughly inoculated with $200 \mathrm{~g}$ of spawn and filled into $80 \times 60 \mathrm{~cm}$ plastic bags. The tops of bags were loosely tied to allow respiration and the substrate was incubated at room temperature, which ranged between 18 and $30^{\circ} \mathrm{C}$.

Three kinds of soil materials were evaluated as casing material. The three soils from the municipality of Lavras, Minas Gerais state, Brazil, were classified as Rhodic Hapludox (RH), Xanthic Hapludox (XH) and Humic Haplaquox (HA). To sample the soils, topsoil was first removed in order to avoid contamination by organic matter, pests and diseases. Each soil sample was sieved (mesh size $1 \mathrm{~cm}$ ) to remove roots and stones. The soil $\mathrm{pH}$ was adjusted to 7.0 using limestone. The soil materials were used without heat treatment or chemical treatments. Charcoal fragments from Eucalyptus were mixed with the Rhodic Hapludox material in the proportion of 4:1 (v:v) (RH:charcoal). Each casing material was adjusted to approximately $65 \%$ moisture.

The colonized compost, after $20 \mathrm{~d}$, was transferred into $14 \mathrm{~L}$ polyethylene pots ( $5 \mathrm{~kg}$ compost per pot) and pressed. A $5 \mathrm{~cm}$ depth of damp casing material was used to cover the colonized compost.

Fructification and production occurred in the same room with the temperature ranging between 16 and 
$30^{\circ} \mathrm{C}$. The air humidity, monitored by a hygrometer, was kept between $75 \%$ and $85 \%$ during all the cultivation. The casing layer was irrigated as necessary. The crop was maintained for 109 days counting from the induction of fruiting.

Mushrooms were harvested twice daily, in the morning and later in the afternoon, when the mushrooms reached the maximum size (approximately 5 $7 \mathrm{~cm}$ ); the sides of the pileus were parallel and before the veil opened. After the uncut mushrooms were harvested, the base of each stipe was cleaned with a brush and the total from each pot weighed. Then, the mushrooms were washed, dried at $60^{\circ} \mathrm{C}$ for $18 \mathrm{~h}$ and wrapped in polypropylene bags.

Productivity (\%) was defined as the ratio of fresh mushrooms harvested per wet substrate (Productivity $=[$ fresh harvest weight/wet weight of substrate $]$ $\times 100])$. Biological efficiency (\%) was defined as the ratio of fresh mushrooms per dry substrate (Biological Efficiency $=[$ fresh harvest weight/dry weight of substrate] $\times 100]$ ).

The experiment was a $2 \times 3$ factorial design (compost formulation $\times$ casing material type) with five replicates of each compost/casing combination, arranged in a completely randomized design. Data were analyzed using a general linear model (Proc GLM; SAS Institute Inc., Cary, NC). Treatment means were separated using Fisher's Least Significant Difference test at 5\% level.

\section{RESULTS AND DISCUSSION}

A significant effect on production was observed both for composts and casing type (Table 1). The Rhodic Hapludox soil material amended with the Eucalyptus charcoal was significantly superior in yield in comparison to the Humic Haplaquox and Xanthic Hapludox materials; and there were no differences between these two, nor was there a significant interac- tion between compost and casing types. When crushed sugarcane bagasse plus corn husk was used as a compost, there was no mushroom harvest when covered by the Humic Haplaquox and Xanthic Hapludox casing materials (Table 1). The Xanthic Hapludox is a clayey soil which tends to cling to the mushrooms and is associated with deformation in the beginning of the production. For this reason grounded Eucalyptus charcoal, which makes the soil more porous, is added to DRL (Eira, 2003). However, we were not able to demonstrate that the addition of charcoal to the casing layer (results not shown) accounted for the difference in production.

Peat is one of the best materials used as casing for the cultivation of $A$. bisporus (Flegg et al., 1985). Porosity, water retention capacity and the presence of bacteria are noted as extremely important characteristics for the fructification induction of this mushroom species (Rainey et al., 1990; Reddy \& Patrick, 1990; Kurtzman, 1995). However, for A. blazei, it is not known which factors are significant for its fruiting. Probably, an interaction between soil microbiota and physical-chemical factors is important to stimulate formation of $A$. blazei fruiting bodies. Different species of bacteria were isolated from the same kinds of soil used in the present work and even after steam pasteurization the bacteria were isolated (Silva et al., 2007).

This study has demonstrated that choice of the soil where the casing material is taken is important for the production of $A$. blazei, regardless of compost formulation. Experiences of failure or great variation in productivity reported among the producers may result from the choice of soil used as a casing material. Evaluations of casing material alternatives by both the academics and the producers are essential for increased productivity and the survival of the A. blazei mushroom industry in Brazil.

Table 1 - Individual mean productivity* and biological efficiency** of compost-casing combinations. The mushroom Agaricus blazei was cultivated on a compost based on crushed sugarcane bagasse and Coastcross hay or crushed sugarcane bagasse and chopped corn husks with corncobs, using three casing materials: Humic Haplaquox, Xanthic Hapludox or Rhodic Hapludox with Eucalyptus charcoal fragments (4:1).

\begin{tabular}{lccrc}
\hline \multirow{2}{*}{$\begin{array}{l}\text { Soil used as source } \\
\text { of case material }\end{array}$} & \multicolumn{4}{c}{ Compost } \\
\cline { 2 - 5 } & \multicolumn{2}{c}{ Sugarcane bagasse + Coastcross hay } & \multicolumn{2}{c}{ Sugarcane bagasse + Corn husk } \\
\cline { 2 - 5 } & Productivity & Biological Efficiency & Productivity & Biological Efficiency \\
\hline Humic Haplaquox & $4.76 \mathrm{c}$ & $15.90 \mathrm{c}$ & $0.00 \mathrm{~b}$ & $0.00 \mathrm{~b}$ \\
Xanthic Hapludox & $7.02 \mathrm{~b}$ & $23.42 \mathrm{~b}$ & $0.00 \mathrm{~b}$ & $0.00 \mathrm{~b}$ \\
Rhodic Hapludox (plus charcoal) & $16.38 \mathrm{a}$ & $54.60 \mathrm{a}$ & $11.18 \mathrm{a}$ & $37.26 \mathrm{a}$ \\
\hline
\end{tabular}

*Productivity $=[$ fresh harvest weight/wet weight of substrate $] \times 100] . * *$ Biological efficieny $=[$ fresh harvest weight/dry weight of substrate] $\times 100]$ 


\section{ACKNOWLEDGEMENTS}

To the "Fundação de Amparo à Pesquisa de Minas Gerais" (FAPEMIG), "Conselho Nacional de Desenvolvimento Científico e Tecnológico" (CNPq) and "Coordenação de Aperfeiçoamento de Pessoal de Nível Superior" (CAPES), for their financial support for the project.

\section{REFERENCES}

EIRA, A.F. Cultivo do cogumelo medicinal Agaricus blazei (Murrill) ss Heinemann ou Agaricus brasiliensis (Wasser et al.). Viçosa: Aprenda Fácil, 2003. 398p.

FLEGG, P.B.; SPENCER, D.M.; WOOD, D.A. The biology and technology of the cultivated mushroom. Chichester: John Wiley, 1985. 177p.

KOPYTOWSKI FILHO, J.; MINHONI, M.T.A.; ESTRADA, A.E.R. Agaricus blazei: "The Almond Portobello" cultivation and commercialization. Mushroom News, v.54, p.22-28, 2006.

KURTZMAN, R.H. Agaricus bisporus (Lange) Imb. casing layer. II. Porosity, the most important character. International Journal of Mushroom Science, v.1,p.11-17, 1995.
RAINEY, P.B.; COLE, A.L.J.; FERMOR, T.R.; WOOD, D.A. A model system for examining involvement of bacteria in basidiome initiation of Agaricus bisporus. Mycology Research, v.94, p.191-195, 1990.

REDDY, M.S.; PATRICK, Z.A. Effect of bacteria associated with mushroom compost and casing materials on basidiomata formation in Agaricus bisporus. Canadian Journal of Plant Pathology, v.12, p.236-242, 1990.

SILVA, V.A.; SOUZA DIAS, E.; VALE, R.H.P.; SILVA, R.; MOREIRA, G.F. Isolation and identification of bacteria present in the casing layer utilized to the cultivation of the mushroom Agaricus blazei Murril. Ciência e Agrotecnologia, v.31, p.1364-1373, 2007.

WASSER, S.P.; DIDUKH, M.Y.; AMAZONAS, M.A.L.A.; NEVO, E.; STAMETS, P.; EIRA, A.F. Is a widely cultivated culinarymedicinal Royal Sun Agaricus (the Himematsutake Mushroom) indeed Agaricus blazei Murrill? International Journal of Medicinal Mushrooms, v.4, p.267-290, 2002.

Received August 03, 2007

Accepted May 15, 2009 